Institute of $\mathbf{F}_{\text {ood and }} \mathbf{A}_{\text {gricultural }} \mathbf{S}_{\text {ciences }}$

\title{
Site Evaluation Form for Selecting the Right Tree for Your Planting Site 1
}

\section{Edward F. Gilman²}

One method of choosing a tree for a particular site is to drive around town to find out which species grow well in landscapes with similar site attributes. The problem with this approach is that most people do not do it, and when they do, it can create urban landscapes with little species diversity. The other problem with this approach is that the soil conditions at your planting site may be different from those at similar sites around town. Many professionals who specify trees for urban and suburban landscapes visit arboreta and botanic gardens. This is a good approach because it potentially brings new plants to our urban landscapes. Others rely on books and computer software to choose trees. This, too, is reasonable, however the specific planting site must first be evaluated to determine the cultural and physical attributes required of trees at the site.

Trees grow when selected according to plant requirements and site condition. In order to maintain trees with the habits and forms that create a desirable design function, one must be sure to choose trees that meet the site's cultural requirements. Before trees can be selected, the site will have to be evaluated to understand these cultural requirements. To accomplish a complete site evaluation one must visit the site and get dirty. There is no substitute. Trees that are able to grow on the site can then be listed using references. Inclusion of ornamental attributes like shape, color, texture, etc. can then narrow the list to a reasonable number of trees to select for planting. The following is a site evaluation form that may serve to guide you through the evaluation process.

Answer the following questions, then bring this completed form to a good reference book or HYPERLINK "http://www.horticopia.com"software program to choose appropriate trees for the planting site.

1. What USDA hardiness zone is the planting site located in?

2. What is the average annual rainfall in the area?

3. Less than 20 inches or More than 20 inches

4. Will the tree be planted:

5. In the ground, in containers or in above ground planters, or near the coast

6. What is the light exposure at the site?

7. More than 6 hours of full sun, between 2 and 5 hours of direct sun, two to five hours of sun with

1. This document is ENH869, one of a series of the Environmental Horticulture Department, Florida Cooperative Extension Service, Institute of Food and Agricultural Sciences, University of Florida. Original publication date July 11, 2002. Visit the EDIS Web Site at http://edis.ifas.ufl.edu.

2. Edward F. Gilman, Professor, Environmental Horticulture, University of Florida, Gainesville, FL 32611

The Institute of Food and Agricultural Sciences is an equal opportunity/affirmative action employer authorized to provide research, educational information and other services only to individuals and institutions that function without regard to race, color, sex, age, handicap, or national origin. For information on obtaining other extension publications, contact your county Cooperative Extension Service office. Florida Cooperative Extension Service/Institute of Food and Agricultural Sciences/University of Florida/Christine Taylor Waddill, Dean. 
significant reflected light, less than 2 hours of full sun, or filtered shade most of the day

8. What is the soil $\mathrm{pH}$ at the planting site? Have it tested, don't guess.

9. How fast does water drain through the soil at the planting site? Test this by digging a hole 18 inches deep and filling it up with water. If the water drains away in an hour or two, the drainage is fast. If it takes up to a day for the water to drain away, drainage is moderate. If it takes longer than a day, the drainage is slow. Slow, moderate, or fast

10. What is the distance between the top of the water table and the soil surface? To test this, dig several holes on the site about 2 feet deep and wait 2 or 3 hours. If any water appears in the hole, the site probably has a high water table.

11. How will the site be irrigated?

12. Hardly at all, during the establishment period only, during establishment and then only during extended drought, the trees will be regularly irrigated.

13. What is the soil texture?

14. Clay, loam, or sand

15. What is the soil density?

16. The soil is compacted and hard, or the soil is loose

17. Will the tree be planted in a tree lawn or streetscape (the grassy strip between the curb and the sidewalk)? If so, how wide is the tree lawn?

18. 3 to 4 feet, 4 to 6 feet, 6 to 8 feet, or more than 8 feet wide

19. Will the tree be planted along a street without a sidewalk. If so, how far from the edge of the road will the tree be planted?

20. Will the tree be planted in a sidewalk cutout?
21. Will the tree be planted in a parking lot? If so, will it be planted in a sidewalk cutout, parking lot island, buffer strip or narrow linear strip of soil?

22. For a parking lot island - what is the square footage of the parking lot island?

23. For a buffer strip or linear strip - what is the width of the buffer strip or liner planting strip?

24. Will the tree be planted in an open lawn area or in a shrub bed? What is the approximate size of this area?

25. Will the tree be planted within 8 feet of a sidewalk, driveway or other hard surface?

26. Will an adjacent sidewalk or roadway receive deicing salts?

27. Is there a swimming pool, vegetable garden, masonry wall or septic tank or drain field within 50 feet of the planting site? I so, how far away is it?

28. Are overhead wires within 30 feet of the planting site? If so, what is the horizontal distance between the planting hole and the wire? What is the distance between the ground and the lowest wire?

29. Is there a street light or security-type light within 35 feet of the planting hole? If so,

30. Do you want the tree branches to stay clear of the light so they will not have to be pruned?

31. Are you willing to provide some pruning to train the branches to grow over the light?

32. What is the horizontal distance between the light and the planting hole?

33. How tall is the light?

34. Is the planting site within 35 feet of a building? If so, what is the horizontal distance between the planting hole and the building? Approximately how tall is the building?

35. Would you care to eliminate trees that could drop messy fruit, large leaves or twigs during an extended period? 
36. Would you like to eliminate trees that are known to be susceptible to breakage?

37. What is your budget for pruning trees?

38. Would you care to plant only native trees?

39. Please list any other attributes that you would like your trees to have?

40. Other considerations: soil salt levels, soil contamination, soil layering, presence of construction debris, health of and type of existing plants, presence of underground utilities. 